\title{
PRESENCE OF ACUTE PHASE RESPONSE IN NORMAL AND MILK FEVER DAIRY COWS AROUND PARTURITION
}

\author{
B. N. Ametaj ${ }^{1 *}$, J. P. Goff', R. L. Horst ${ }^{2}$, B. J. Bradford ${ }^{1}$, and D. C. Beitz ${ }^{1}$ \\ ${ }^{1}$ Iowa State University, Ames, IA, USA; ${ }^{2}$ National Animal Disease Center, USDA, ARS, Ames, IA, USA \\ *313C Kildee Hall, Department of Animal Science, Iowa State University, Ames, IA 50011
}

Milk fever is a metabolic disease of dairy cows occurring at the onset of lactation and characterized by a rapid decline in the concentrations of calcium in plasma. Significant advances have been made during the last decade in the understanding of the pathogenesis of milk fever. The etiology of the disease, however, still remains unclear. The goal of the present study was to search for the presence of an acute phase response (APR) during the peripartal period in normal and milk fever dairy cows and the role that APR might play in the etiology of milk fever. Eight clinically healthy, pregnant Holstein dairy cows were selected. Approximately 3 wk before the expected date of calving as well as 2 wk after calving, animals were brought into individual tie stalls to be fed a diet with a cation-anion difference of $+40 \mathrm{meq} / 100 \mathrm{~g}$. Three cows showed clinical signs of milk fever and were treated intravenously with a solution containing calcium borogluconate and magnesium gluconate, whereas the rest of the cows showed no clinical signs of postparturient diseases. Blood samples were obtained from jugular vein at 10,5 , and $1 \mathrm{~d}$ before parturition, on the day of parturition, as well as at 1,5 , and $10 \mathrm{~d}$ after parturition. Plasma samples were analyzed for serum amyloid A (SAA), calcitonin generelated peptide (CGRP), tumor necrosis factor-alpha (TNF- $\alpha$ ), lactate, iron, and total calcium. Results show that concentrations of SAA in plasma from all cows increased from $706 \mu \mathrm{g} / \mathrm{dL}$ at $10 \mathrm{~d}$ before calving to $3096 \mu \mathrm{g} / \mathrm{dL} 1 \mathrm{~d}$ after calving and then declined to prepartal values. Concentrations of lactate in plasma also increased from $0.5 \mathrm{mmol} / \mathrm{L}$ at $10 \mathrm{~d}$ before parturition to $1.3 \mathrm{mmol} / \mathrm{L}$ on the day of parturition and then dropped to precalving values. Concentrations of iron and total calcium in plasma declined in both control and milk fever cows from $57 \mu \mathrm{g} / \mathrm{dL}$ and $8.7 \mathrm{mg} / \mathrm{dL}$ at $10 \mathrm{~d}$ before calving to $41 \mu \mathrm{g} / \mathrm{dL}$ and $6.4 \mathrm{mg} / \mathrm{dL}$, respectively, on the day of parturition and then increased to precalving concentrations. Analysis showed detectable amounts of TNF- $\alpha$ in plasma of only one clinically normal cow. Concentrations of CGRP in plasma were high in both milk fever and normal cows before parturition at $59 \mathrm{pg} / \mathrm{mL}$ and then declined after calving at $27 \mathrm{pg} / \mathrm{mL}$. Concentrations of SAA and iron in plasma were greater in milk fever cows compared with clinically normal ones at the day of parturition. Overall, data from the present study indicate the presence of an APR in both normal and milk fever cows. Calcitonin gene-related peptide, a 37-amino acid peptide generated by alternative tissue-specific splicing of the transcript of the calcitonin gene and a well-known inhibitor of calcium mobilization from bone in rodents, might play a significant role in regulation of calcium homeostasis as well as in the etiology and pathogenesis of milk fever in dairy cows. Further investigation is warranted to better understand the role of APR in the etiology and pathogenesis of milk fever of dairy cows. 